\title{
ANALYSIS OF BAUXITE AND OF REFRACTORIES OF HIGH ALUMINA CONTENT
}

\author{
By G. E. F. Lundell and J. I. Hoffman
}

\begin{abstract}
A study has been made of the analytical details involved in the analysis of bauxite and burnt refractories of high alumina content. The work has shown that an accurate analysis of these materials is a far more difficult problem than it is ordinarily thought to be. In spite of the fact that the determination of alumina is usually regarded as very simple, extreme values of 54.84 and 56.68 per cent were reported by the analysts who cooperated on the analysis of the Bureau of Standards standard sample of bauxite No. 69 (actual $\mathrm{Al}_{2} \mathrm{O}_{3}, 55.06$ per cent). The results for alumina and silica reported in the analysis of the standard burnt refractories Nos. 76, 77, and 78 were even less satisfactory. The improper drying of bauxite and the difficulty of putting burnt refractories into complete solution were found to be sources of error.

Other sources of error, such as improper ignition of precipitates of aluminum hydroxide, misleading corrections for impurities derived from reagents, etc., are pointed out. An umpire method is given for the determination of $\mathrm{SiO}_{2}, \mathrm{Al}_{2} \mathrm{O}_{3}$, $\mathrm{P}_{2} \mathrm{O}_{5}, \mathrm{Cr}_{2} \mathrm{O}_{3}, \mathrm{~V}_{2} \mathrm{O}_{5}, \mathrm{Fe}_{2} \mathrm{O}_{3}, \mathrm{TiO}_{2}, \mathrm{ZrO}_{2}, \mathrm{CaO}$, and $\mathrm{MgO}$. In addition, a routine method for $\mathrm{Al}_{2} \mathrm{O}_{3}$ is described. In this method the solution of the sample is divided into three aliquots. In the first aliquot the $\mathrm{Al}_{2} \mathrm{O}_{3}, \mathrm{Fe}_{2} \mathrm{O}_{3}, \mathrm{TiO}_{2}, \mathrm{ZrO}_{2}$, $\mathrm{P}_{2} \mathrm{O}_{5}$, and $\mathrm{V}_{2} \mathrm{O}_{5}$ are precipitated by $\mathrm{NH}_{4} \mathrm{OH}$. In the second aliquot the $\mathrm{Fe}_{2} \mathrm{O}_{3}$, $\mathrm{TiO}_{2}, \mathrm{ZrO}_{2}$, and $\mathrm{V}_{2} \mathrm{O}_{5}$ are precipitated by cupferron. In the third aliquot the $\mathrm{P}_{2} \mathrm{O}_{5}$ is determined. The $\mathrm{Al}_{2} \mathrm{O}_{3}$ is then found by difference.
\end{abstract}

\section{CONTENTS}

II. Methods of analysis_...

1. Precautions__._.

(a) Drying

(b) Solution of the sample

(c) Silica

(d) Alumina_........... 95

2. Umpire method for the analysis of bauxite or refractories of high alumina content

(a) Drying _............ 96

(b) Solution of the sample_........ 97

(c) Determination of silica _._._._.

(d) Determination of the mixed oxides_........... 98

(e) Recovery of silica

(f) Determination of $\mathrm{P}_{2} \mathrm{O}_{5}, \mathrm{Cr}_{2} \mathrm{O}_{3}$, and $\mathrm{V}_{2} \mathrm{O}_{5} \ldots \ldots$ 
II. Methods of analysis-Continued.

2. Umpire method for the analysis of bauxite or refractories of high alumina content-Continued

(g) Determination of $\mathrm{Fe}_{2} \mathrm{O}_{3}, \mathrm{TiO}_{2}$ and $\mathrm{ZrO}_{2}(\mathrm{HfO}) \quad$ Page

(h) Determination of lime and magnesia

(i) Determination of the alkalies_._..._............. 102

3. Routine method for the determination of alumina in bauxite or refractories of high alumina content _... 102

(a) Precipitation by ammonium hydroxide............ 103

(b) Precipitation of $\mathrm{Fe}_{2} \mathrm{O}_{3}$, $\mathrm{TiO}_{2}$, etc., by cupferron ........ 103

(c) Determination of $\mathrm{P}_{2} \mathrm{O}_{5} \ldots \ldots$

\section{GENERAL CONSIDERATIONS}

An accurate analysis of bauxite or of refractories of high alumina content is a far more difficult problem than is ordinarily thought. For example, in the A. S. T. M. Standards (1924), page 749, it is stated that-

It shall be considered satisfactory if the differences between check determinations (in refractories) do not exceed the following limits: For silica or other constituents amounting to 30 per cent or over, 0.3 per cent; for alumina or other constituents amounting to 10 to 30 per cent, 0.2 per cent; and for any other constituent amounting to under 10 per cent, 0.1 per cent.

In contrast to these expectations the data given in Table 1 show the extreme values and the average deviation from the standard values for the first analyses reported on Bureau of Standards standard samples of burnt refractories Nos. 76, 77, and 78. Furthermore, in determinations of the percentage of $\mathrm{Al}_{2} \mathrm{O}_{3}$ in the bureau sample of bauxite No. 69 (55.06 per cent $\mathrm{Al}_{2} \mathrm{O}_{3}$ ) the extreme values reported were 54.84 and 56.68 , and the average deviation from the standard value was 0.59 per cent.

TABLE 1.-Results reported in first analyses of Bureau of Standards analyzed refractories

\begin{tabular}{|c|c|c|c|c|c|c|c|c|c|}
\hline \multirow[b]{2}{*}{ Constituent } & \multicolumn{3}{|c|}{ Sample No. 76} & \multicolumn{3}{|c|}{ Sample No. 77} & \multicolumn{3}{|c|}{ Sample No. 78} \\
\hline & $\begin{array}{c}\text { Recom- } \\
\text { mended } \\
\text { value }\end{array}$ & $\begin{array}{c}\text { Extreme } \\
\text { values }\end{array}$ & $\begin{array}{l}\text { Aver- } \\
\text { age de- } \\
\text { viation }\end{array}$ & $\begin{array}{c}\text { Recom- } \\
\text { mended } \\
\text { value }\end{array}$ & $\begin{array}{l}\text { Extreme } \\
\text { values }\end{array}$ & $\begin{array}{l}\text { Aver- } \\
\text { age de- } \\
\text { viation }\end{array}$ & $\begin{array}{c}\text { Recom- } \\
\text { mended } \\
\text { value }\end{array}$ & $\begin{array}{l}\text { Extreme } \\
\text { values }\end{array}$ & $\begin{array}{l}\text { Aver- } \\
\text { age de- } \\
\text { viation }\end{array}$ \\
\hline $\begin{array}{l}\mathrm{SiO}_{2 \ldots} \\
\mathrm{Al}_{2} \mathrm{O}_{3} \ldots \\
\mathrm{Fe}_{2} \mathrm{O}_{3} \\
\mathrm{TiO}_{2} \\
\mathrm{CaO} \\
\mathrm{MgO} \\
\mathrm{K}_{2} \mathrm{O}_{\ldots} \\
\mathrm{Na}_{2} \mathrm{O}_{\ldots}\end{array}$ & $\begin{array}{r}54.68 \\
37.67 \\
2.38 \\
2.21 \\
.27 \\
.58 \\
1.37 \\
.38\end{array}$ & $\begin{array}{r}53.02-55.00 \\
37.47-40.81 \\
.85-3.69 \\
.10-2.70 \\
.11-.95 \\
.08-.71 \\
.87-1.43 \\
.09-1.66\end{array}$ & $\begin{array}{l}0.43 \\
.76 \\
.37 \\
.35 \\
.21 \\
.23 \\
.26 \\
.53\end{array}$ & $\begin{array}{r}32.38 \\
59.39 \\
.90 \\
2.93 \\
.25 \\
.50 \\
2.11 \\
.86\end{array}$ & $\begin{array}{r}30.20-32.76 \\
58.82-61.67 \\
.75-3.46 \\
.14-3.10 \\
.19-.48 \\
.09-.58 \\
1.16-2.10 \\
.43-2.17\end{array}$ & $\begin{array}{l}0.58 \\
1.33 \\
.46 \\
.35 \\
.10 \\
.18 \\
.63 \\
.59\end{array}$ & $\begin{array}{r}20.69 \\
69.97 \\
.79 \\
3.37 \\
.38 \\
.51 \\
2.83 \\
.53\end{array}$ & $\begin{array}{r}18.26-21.64 \\
69.23-74.36 \\
.63-3.38 \\
.17-3.60 \\
.28-.65 \\
.03-.70 \\
1.84-2.90 \\
.32-1.72\end{array}$ & $\begin{array}{l}0.51 \\
1.68 \\
.43 \\
.59 \\
.09 \\
.19 \\
.66 \\
.47\end{array}$ \\
\hline
\end{tabular}

It is significant that the differences between the determinations for $\mathrm{SiO}_{2}$ and for $\mathrm{Al}_{2} \mathrm{O}_{3}$ were from 7 to 17 times greater than the specified tolerances, and that out of 28 analyses of the refractories 17 results for $\mathrm{SiO}_{2}$ were lower and 11 were higher than the actual content, while for $\mathrm{Al}_{2} \mathrm{O}_{3}, 6$ results were lower and 22 were higher. 
It is apparent that there is room for considerable improvement in the analysis of such materials, in spite of the attention that has been paid to methods for determining $\mathrm{SiO}_{2}, \mathrm{Al}_{2} \mathrm{O}_{3}$, and the like. This paper accordingly sets forth suggested umpire procedures, together with such precautions as have been found necessary. In addition, a routine method is suggested for the determination of $\mathrm{Al}_{2} \mathrm{O}_{3}$, particularly in bauxite, which provides a simple direct determination of $\mathrm{P}_{2} \mathrm{O}_{5}$ and obviates the necessity of separate determinations of and deduction for such constituents as $\mathrm{Fe}_{2} \mathrm{O}_{3}, \mathrm{TiO}_{2}, \mathrm{ZrO}_{2}$, and $\mathrm{V}_{2} \mathrm{O}_{5}$, all of which may be present and must be guarded against.

\section{METHODS OF ANALYSIS}

\section{PRECAUTIONS}

(a) Drying.-The moisture content of powdered bauxite varies with atmospheric conditions. In tests made at the Bureau of Standards it was found necessary to dry samples for two hours at $140^{\circ} \mathrm{C}$. in order to obtain reproducible results. Material thus dried is so hygroscopic that each portion of sample taken for analysis must be separately dried. Burnt refractories present very little difficulty in drying. Reproducible samples can be obtained by drying for one hour at 105 to $110^{\circ} \mathrm{C}$., and the dried samples are not appreciably hygroscopic.

(b) Solution of the Sample.-Bauxite can be almost entirely decomposed by a mixture of $\mathrm{HF}, \mathrm{HNO}_{3}$, and $\mathrm{H}_{2} \mathrm{SO}_{4}$. Such an attack is more convenient than a fusion procedure because the introduction of foreign salts is avoided and $\mathrm{SiO}_{2}$ is eliminated. $\mathrm{HF}$ must afterwards be entirely expelled by fuming with $\mathrm{H}_{2} \mathrm{SO}_{4}$, or the subsequent precipitation of aluminum by $\mathrm{NH}_{4} \mathrm{OH}$ will be incomplete, and any insoluble residue must be recovered, fused, and put into solution.

Burnt refractories do not respond as well to a wet attack. For these, as well as for bauxite, when $\mathrm{SiO}_{2}$ is to be determined, recourse must be had to a fusion method. $\mathrm{Na}_{2} \mathrm{CO}_{3}, \mathrm{Na}_{2} \mathrm{O}_{2}, \mathrm{~K}_{2} \mathrm{~S}_{2} \mathrm{O}_{7}$, or $\mathrm{Na}_{2} \mathrm{~S}_{2} \mathrm{O}_{7}$ are satisfactory fluxes. At the Bureau of Standards 7 to $10 \mathrm{~g}$ of $\mathrm{Na}_{2} \mathrm{CO}_{3}$ was used for the fusion of a $1 \mathrm{~g}$ sample, and the full temperature of a Méker burner was maintained for at least one hour. Of the cooperating analysts, W. F. Muehlberg, of the Newburgh Steel Works, obtained satisfactory results in the analysis of bauxite by exploding the sample in a mixture of $\mathrm{Na}_{2} \mathrm{O}_{2}$ and sugar carbon, ${ }^{1}$ while L. P. Chase, ${ }^{2}$ of the Illinois Steel Co., fused the burnt refractories with $\mathrm{K}_{2} \mathrm{~S}_{2} \mathrm{O}_{7}$. According to M. O. Lamar, ${ }^{2}$ of the Norton Co.,

1 W. F. Muehlberg, Ind. Eng. Chem., 1\%, p. 690; 1925.

${ }^{2}$ Private communication. 
satisfactory fusions of calcined bauxite are obtained through the use of equal parts of $\mathrm{Na}_{2} \mathrm{CO}_{3}$ and fused $\mathrm{Na}_{2} \mathrm{~B}_{4} \mathrm{O}_{7}{ }^{3}$

The melt can be dissolved in dilute $\mathrm{HCl}$ or $\mathrm{H}_{2} \mathrm{SO}_{4}$, depending upon which reagent is preferred for the dehydration of $\mathrm{SiO}_{2}$. If there is any evidence of incomplete decomposition of the sample after either wet or fusion attack, much trouble can be avoided by filtering off the insoluble matter, igniting, fusing with $\mathrm{K}_{2} \mathrm{~S}_{2} \mathrm{O}_{7}$ or $\mathrm{Na}_{2} \mathrm{~S}_{2} \mathrm{O}_{7}$, and dissolving the melt in the original solution before proceeding with the analysis.

(c) SilicA.-Two dehydrations with $\mathrm{HCl}$ or $\mathrm{H}_{2} \mathrm{SO}_{4}$ are sufficient in routine work. If $\mathrm{HCl}$ is used, the temperature of dehydration should not exceed 105 to $110^{\circ} \mathrm{C}$. on account of the formation of insoluble aluminum compounds. If $\mathrm{H}_{2} \mathrm{SO}_{4}$ is used, a liberal excess must be present to keep the dehydrated mass from forming a solid cake which renders subsequent solution of the salts most difficult.

The first $\mathrm{SiO}_{2}$ recovered must be very thoroughly washed with hot dilute $\mathrm{HCl}(5: 95)^{4}$ and then with hot water to remove salts of aluminum and the alkalies. The smaller second recovery is washed with cool dilute $\mathrm{HCl}(1: 99)$ and then with hot water. The temperature at which $\mathrm{SiO}_{2}$ is finally heated must not be less than $1,200^{\circ} \mathrm{C}$., and the heating must be continued until constant weight is obtained. As the ignited oxide is somewhat hygroscopic, the crucible should be covered with a well-fitting cover during cooling and weighing, and the desiccator should contain a strong desiccant.

In analyses of the highest accuracy the $\mathrm{SiO}_{2}$ that escapes two dehydrations must be recovered in the second filtrate by precipitating with $\mathrm{NH}_{4} \mathrm{OH}$, dissolving the precipitate in dilute $\mathrm{H}_{2} \mathrm{SO}_{4}$, evaporating to fumes of $\mathrm{H}_{2} \mathrm{SO}_{4}$, diluting and filtering. Less accurate, because of the solvent action of $\mathrm{KHSO}_{4}$ or $\mathrm{NaHSO}_{4}$, but satisfactory for most purposes, is the recovery based on the fusion of the weighed oxides as under the umpire method. The amount that is recovered varies. In analyses of a series of refractories with $\mathrm{SiO}_{2}$ content ranging from 20 to 60 per cent the recoveries averaged 0.2 per cent in either $\mathrm{HCl}$ or $\mathrm{H}_{2} \mathrm{SO}_{4}$ dehydration. It is not safe, however, to arbitrarily add this amount of $\mathrm{SiO}_{2}$, because in some cases as little

${ }^{3}$ If $\mathrm{Na}_{2} \mathrm{~B}_{4} \mathrm{O}_{7}$ is used, it must be removed before determinations of $\mathrm{SiO}_{2}$ or $\mathrm{Al}_{2} \mathrm{O}_{3}$ are attempted, for otherwise part of the boron is carried down by $\mathrm{SiO}_{2}$ and volatilized as the fluoride, $\mathrm{BF}_{3}$, while part is carried down by the $\mathrm{NH}_{4} \mathrm{OH}$ precipitate in spite of reprecipitations. Boron can be removed as follows: Place the melt in a large porcelain or platinum dish, cover and treat with a saturated solution of $\mathrm{HCl}$ in $\mathrm{CH}_{3} \mathrm{OH}$ (prepared by passing dry $\mathrm{HCl}$ gas into cooled $\mathrm{CH}_{3} \mathrm{OH}$ for one to two hours). When effervescence ceases, remove the cover and heat just short of boiling, preferably on a water bath in a good hood. Cleanse the crucible in a similar manner and add its contents to the dish. Add more reagent as necessary until solution is complete, boil to a small volume and evaporate to dryness on the bath. To remove the last traces of boron, evaporate to dryness at 80 to $85^{\circ} \mathrm{C}$. on the bath two or three times with successive additions of small portions of the reagent, taking care to wash down the sides of the dish.

${ }^{4}$ Prepared by mixing $5 \mathrm{ml}$ of $\mathrm{HCl}$ sp. gr. 1.19 , with $95 \mathrm{ml}$ of water. This system of designating dilute acids is used throughout the paper. For example, dilute $\mathrm{H}_{2} \mathrm{SO}_{4}(1: 1)$, denotes a solution containing $50 \mathrm{ml}$ of $\mathrm{H}_{2} \mathrm{SO}_{1}$, sp. gr. 1.84 , and $50 \mathrm{ml}$ of water. 
as 0.04 per cent was recovered while in others the recovery amounted to 0.3 per cent.

(d) Alumina.- The chief sources of error in a determination of $\mathrm{Al}_{2} \mathrm{O}_{3}$ in bauxite or refractories high in $\mathrm{Al}_{2} \mathrm{O}_{3}$ are:

1. Failure to completely decompose the material. Whenever there is doubt as to the completeness of decomposition, the residue left after dissolving the melt should be fused, dissolved, and added to the original solution.

2. Failure to fuse the nonvolatile residue left after the treatment of the $\mathrm{SiO}_{2}$ with $\mathrm{HF}$ and $\mathrm{H}_{2} \mathrm{SO}_{4}$. This residue must be fused, the melt dissolved, and the solution added to the filtrate from the $\mathrm{SiO}_{2}$.

3. Failure to correct for all of the compounds that are normally carried down in the $\mathrm{NH}_{4} \mathrm{OH}$ precipitate and weighed with the $\mathrm{Al}_{2} \mathrm{O}_{3}$. The following list of such compounds that are contained in the Bureau of Standards sample of bauxite No. 69 illustrates the extent of the errors that may be made if any or all of such corrections are omitted: $\mathrm{Fe}_{2} \mathrm{O}_{3}, 5.66$ per cent; $\mathrm{TiO}_{2}, 3.07$ per cent; $\mathrm{ZrO}_{2}, 0.08$ per cent; $\mathrm{P}_{2} \mathrm{O}_{5}, 0.11$ per cent; $\mathrm{V}_{2} \mathrm{O}_{3}, 0.03$ per cent; and $\mathrm{Cr}_{2} \mathrm{O}_{3}, 0.04$ per cent.

4. Failure to remove the alkali salts carried down by the $\mathrm{NH}_{4} \mathrm{OH}$ precipitate. For example, after fusion of $0.5 \mathrm{~g}$ of bauxite with 7 to $10 \mathrm{~g}$ of $\mathrm{Na}_{2} \mathrm{CO}_{3}$ and elimination of $\mathrm{SiO}_{2}$, the alkali salts in the ignited mixed oxides as determined by the J. Lawrence Smith method amounted to $0.7 \mathrm{mg}$ after careful double precipitation and $0.1 \mathrm{mg}$ after triple precipitation by $\mathrm{NH}_{4} \mathrm{OH}$. The error caused by the retention of alkalies may, therefore, be as high as 0.14 per cent of $\mathrm{Al}_{2} \mathrm{O}_{3}$ (on a $0.5 \mathrm{~g}$ sample) in spite of double precipitations and will be much greater if only a single precipitation is made.

5. Improper ignition of the $\mathrm{NH}_{4} \mathrm{OH}$ precipitate. Blum ${ }^{5}$ has shown that $\mathrm{Al}_{2} \mathrm{O}_{3}$ which has been heated over the blast lamp to constant weight undergoes no further loss upon heating to 1,440 to $1,460^{\circ} \mathrm{C}$. As a result of his tests he states that ignition for 5 to 10 minutes over a blast lamp is sufficient to bring $\mathrm{Al}_{2} \mathrm{O}_{3}$ to constant weight. This statement is correct for small precipitates obtained from pure solutions. In ignitions of the large mixed precipitate obtained from bauxite or refractories the analyst must be sure that he is igniting at at least $1,200^{\circ} \mathrm{C}$. and that constant weight has been obtained. For example, a precipitate containing $0.35 \mathrm{~g}$ of $\mathrm{Al}_{2} \mathrm{O}_{3}$ lost but $0.1 \mathrm{mg}$ when heated in a muffle for one hour at $900^{\circ} \mathrm{C}$. after a preliminary heating for a like period at $800^{\circ} \mathrm{C}$. When heated for one hour at $1,050^{\circ} \mathrm{C}$., it lost $1.4 \mathrm{mg}$, and upon heating over the blast it lost $1.5 \mathrm{mg}$ more, both corrected for the loss of weight of the platinum crucible. The error caused by the retention

${ }^{5}$ B. S. Sci. Paper No. 286; J. Am. Chem. Soc., 38, p. 1282; 1916.

$2284^{\circ}-28-7$ 
of water would therefore, have been 0.58 per cent of $\mathrm{Al}_{2} \mathrm{O}_{3}$ (on a $0.5 \mathrm{~g}$ sample) if heating had been stopped at $900^{\circ} \mathrm{C}$. and 0.30 per cent if it had been stopped at $1,050^{\circ} \mathrm{C}$.

6. Failure to protect the ignited residue from moisture before or during weighing. Ignited $\mathrm{Al}_{2} \mathrm{O}_{3}$ absorbs water readily and takes up in the first few minutes a large proportion of the water that it will absorb in 24 hours. This is important, as the atmosphere in a desiccator immediately after opening is not much different from that of the room. Fortunately, the rate of absorption is very slow if the crucible is covered with a well-fitting lid during cooling and weighing, and errors are negligible if a good desiccant is used in the desiccator and weighings are made rapidly. For example, a well-covered crucible containing $0.1 \mathrm{~g}$ of ignited $\mathrm{Al}_{2} \mathrm{O}_{3}$ showed no appreciable change in weight in five minutes on the balance pan but gained $1 \mathrm{mg}$ in five minutes when uncovered. An oxide ignited at $1,200^{\circ} \mathrm{C}$. is less hygroscopic than one ignited at $1,000^{\circ} \mathrm{C}$.

7. Failure to correct for $\mathrm{SiO}_{2}$ carried down by the $\mathrm{NH}_{4} \mathrm{OH}$ precipitate. $\mathrm{SiO}_{2}^{-}$is always carried down by the $\mathrm{NH}_{4} \mathrm{OH}$ precipitate, and the amount depends on the completeness of the recovery of $\mathrm{SiO}_{2}$ at the start of the analysis and the amount afterwards introduced with the reagents, chiefly through $\mathrm{NH}_{4} \mathrm{OH} . \mathrm{SiO}_{2}$ is always left in solution, even after double dehydration with $\mathrm{HCl}$ or $\mathrm{H}_{2} \mathrm{SO}_{4}$. In careful analyses the amount (on a $0.5 \mathrm{~g}$ sample) may represent as little as 0.05 per cent of $\mathrm{Al}_{2} \mathrm{O}_{3}$ and as much as 0.3 per cent.

8. Misleading corrections for impurities derived from the reagents or through attack on the vessels used. The small precipitate obtained by precipitation with $\mathrm{NH}_{4} \mathrm{OH}$ in a solution of reagents alone does not, as a rule, carry down impurities, such as $\mathrm{SiO}_{2}$ or $\mathrm{P}_{2} \mathrm{O}_{5}$, introduced through the reagents or during the analysis, as completely as does the much larger precipitate obtained from the material under analysis. For example, in analyses of $0.5 \mathrm{~g}$ portions of bauxite, an average correction of $0.25 \mathrm{mg}$ was indicated by the reagents alone, $1.8 \mathrm{mg}$ when $0.25 \mathrm{~g}$ of $\mathrm{Al}_{2} \mathrm{O}_{3}$ as pure $\mathrm{AlCl}_{3}$ was added to the reagents and no correction for $\mathrm{SiO}_{2}$ was made, and $0.9 \mathrm{mg}$ when $\mathrm{AlCl}_{3}$ was added and correction for $\mathrm{SiO}_{2}$ was made. If the correction was based on reagents alone, the result for $\mathrm{Al}_{2} \mathrm{O}_{3}$ in the bauxite would, therefore, be high and differ by 0.13 from the true percentage. On the other hand, if no correction was made for the $\mathrm{SiO}_{2}$ carried down by the added $\mathrm{Al}_{2} \mathrm{O}_{3}$ the result would be low and differ by 0.18 per cent from the true value.

\section{UMPIRE METHOD FOR THE ANALYSIS OF BAUXITE OR REFRAC- TORIES OF HIGH ALUMINA CONTENT}

(a) Drying.--Transfer a portion of the sample to a weighing bottle of such diameter that the layer of sample is not more than one-half 
centimeter deep. Dry bauxite for two hours at $140^{\circ} \mathrm{C}$. and burnt refractories for one hour at 105 to $110^{\circ} \mathrm{C}$. Cool over a good desiccant. In the most accurate analyses of bauxite each portion taken for analysis should be separately dried and the weight obtained by stoppering the bottle, cooling in a desiccator, lifting the cover for an instant, weighing, pouring out as much of the powder as possible without brushing, and again weighing.

(b) Solution of the Sample.-Thoroughly mix $0.5000 \mathrm{~g}$ of the dried sample with 7 to $8 \mathrm{~g}$ of $\mathrm{Na}_{2} \mathrm{CO}_{3}$ in a platinum crucible and cover the mixture with an additional gram of $\mathrm{Na}_{2} \mathrm{CO}_{3}$. Gradually, particularly with bauxite, heat the covered crucible and its contents until the mass is molten. After the mass is molten and the fusion is quiet grasp the crucible with a pair of tongs, slightly tilt and rotate it, so as to decompose particles which cling to the sides of the crucible above the molten mass. Finally heat at 1,000 to $1,100^{\circ} \mathrm{C}$. for one hour. Cool and dissolve the melt in a platinum dish in $150 \mathrm{ml}$ of dilute $\mathrm{H}_{2} \mathrm{SO}_{4}(1: 9)$. If there is any indication of incomplete decomposition, filter the solution, wash the residue, and ignite the paper in the crucible used for the fusion. Fuse the residue with a small amount of $\mathrm{Na}_{2} \mathrm{CO}_{3}$ and add the cooled melt to the original solution.

If $\mathrm{SiO}_{2}$ is not to be determined, bauxite can be almost entirely decomposed by the use of $\mathrm{HF}, \mathrm{HNO}_{3}$, and $\mathrm{H}_{2} \mathrm{SO}_{4}$ as described in the routine method. Burnt refractories are only partially decomposed by such treatment.

(c) Determination of Silica.-Evaporate the solution until fumes of $\mathrm{H}_{2} \mathrm{SO}_{4}$ appear, cool, and take up in $200 \mathrm{ml}$ of water. Heat until the salts are in solution, and immediately filter through a No. 40 Whatman or similar paper. Wash very thoroughly with warm dilute $\mathrm{HCl}(5: 95)$ and finally with hot water. It is very important that the $\mathrm{SiO}_{2}$ be washed free from sodium salts. Reserve the paper and residue. Again evaporate the filtrate until fumes of $\mathrm{H}_{2} \mathrm{SO}_{4}$ appear and treat as before except that the residue should be washed with cool dilute $\mathrm{HCl}(1: 99)$ instead of with the hot $5: 95$ acid. Reserve the filtrate (A). Char the two papers containing the $\mathrm{SiO}_{2}$ in a platinum crucible, burn the carbon at as low a temperature as possible, and finally heat at approximately $1,200^{\circ} \mathrm{C}$. Cool over a good desiccant and weigh. The heating should be very gentle at first to avoid mechanical loss of very finely powered $\mathrm{SiO}_{2}$, and the crucible must be tightly covered during the final heating. If a blast lamp is used, the crucible should be set to two-thirds of its depth in an asbestos shield.

After constant weight has been attained carefully moisten the $\mathrm{SiO}_{2}$ in the crucible and add a few drops of $\mathrm{H}_{2} \mathrm{SO}_{4}(1: 1)$ and approximately $10 \mathrm{ml}$ of HF. Evaporate, carefully expel the $\mathrm{H}_{2} \mathrm{SO}_{4}$, and again ignite to constant weight. The difference between the two 
weights is $\mathrm{SiO}_{2}$. To this must be added the $\mathrm{SiO}_{2}$ recovered from the mixed oxides.

(d) Determination of the Mixed Oxides. - Fuse the nonvolatile residue from the $\mathrm{SiO}_{2}$ with a small quantity of $\mathrm{K}_{2} \mathrm{~S}_{2} \mathrm{O}_{7}$, cool, take up the melt in dilute $\mathrm{H}_{2} \mathrm{SO}_{4}(1: 9)$, and add the solution to the filtrate from the determination of $\mathrm{SiO}_{2}$ (A). Dilute this solution to $350 \mathrm{ml}$, add a few drops of methyl red indicator, heat to boiling and add $\mathrm{NH}_{4} \mathrm{OH}$ until the red color just changes to a light yellow. Boil for one to three minutes and, if the red color of the indicator reappears, discharge it by adding another drop of $\mathrm{NH}_{4} \mathrm{OH}$. Filter through a No. 40 Whatman or similar paper and wash the precipitate 5 to 10 times with a hot neutral 2 per cent solution of $\mathrm{NH}_{4} \mathrm{Cl}$. Return the precipitate to the beaker in which the precipitation was made by washing it off the paper with a strong jet of water and dissolve it in $50 \mathrm{ml}$ of hot dilute HCl $(1: 1)$. When the precipitate has dissolved, dilute to 350 to $400 \mathrm{ml}$, add the paper, stir until pulped, and repeat the precipitation and washing as before. Do not allow the precipitate to run dry on the filter, but keep the paper filled or nearly filled with wash solution. At least $250 \mathrm{ml}$ of solution should be used in the final washing. If the precipitate is too large to go into the crucible, dry the paper and contents at 100 to $110^{\circ} \mathrm{C}$. and then transfer to a platinum crucible that has been weighed with cover. Ignite at a low temperature and under good oxidizing conditions at first and finally cover and heat at approximately $1,200^{\circ} \mathrm{C}$. Cool over a good desiccant, never $\mathrm{CaCl}_{2}$, and weigh quickly. Repeat the heating and weighing until constant weight is obtained. The precipitate contains the $\mathrm{Al}_{2} \mathrm{O}_{3}, \mathrm{Fe}_{2} \mathrm{O}_{3}, \mathrm{TiO}_{2}, \mathrm{ZrO}_{2}, \mathrm{P}_{2} \mathrm{O}_{5}, \mathrm{~V}_{2} \mathrm{O}_{5}, \mathrm{Cr}_{2} \mathrm{O}_{3}{ }^{6}$ which were present in the sample, besides the $\mathrm{SiO}_{2}$ which escaped the double dehydration.

In order to arrive at the true weight of $\mathrm{Al}_{2} \mathrm{O}_{3}$, it is necessary to determine the weights of the other substances as described below and to subtract from the total weight. As the quantities of the accompanying substances are relatively small, this method of obtaining $\mathrm{Al}_{2} \mathrm{O}_{3}$ (by difference) yields results that are quite acceptable, although an accuracy better than 1 part in 200 can hardly be expected.

(e) Recovery of Silica.-Fuse the mixed oxides with $\mathrm{K}_{2} \mathrm{~S}_{2} \mathrm{O}_{7}$, cool, and dissolve the melt in $100 \mathrm{ml}$ of dilute $\mathrm{H}_{2} \mathrm{SO}_{4}(1: 9)$. Evaporate to incipient fumes of $\mathrm{H}_{2} \mathrm{SO}_{4}$, cool, add 150 to $200 \mathrm{ml}$ of warm water, heat until the salts are in solution, and immediately filter and wash the small amount of $\mathrm{SiO}_{2}$. Reserve the filtrate (B). Ignite, weigh, treat with $\mathrm{HF}$ and $\mathrm{H}_{2} \mathrm{SO}_{4}$ as previously described, and again weigh. Add this $\mathrm{SiO}_{2}$ to that previously obtained. Fuse the small

\footnotetext{
${ }^{6} \mathrm{Cr}_{2} \mathrm{O}_{3}$ by itself is partially oxidized during ignition and is no doubt partly oxidized during the ignition of the mixed oxides. If the total amount involved is small, as in the usual case, no appreciable error is caused if calculations are based on the oxide, $\mathrm{Cr}_{2} \mathrm{O}_{3}$. If large amounis of chromium are present, as in chrome brick, accurate results can only be obtained by determining the chromium (preferably by volumetric titration) in a separate portion of sample and oxidizing it to the chromate before the mixed oxides are precipitated.
} 
nonvolatile residue with a little $\mathrm{K}_{2} \mathrm{~S}_{2} \mathrm{O}_{7}$, dissolve the melt in dilute $\mathrm{H}_{2} \mathrm{SO}_{4}$, and add to the reserved filtrate (B).

( $f$ ) Determination of $\mathrm{P}_{2} \mathrm{O}_{5}, \mathrm{Cr}_{2} \mathrm{O}_{3}$, ANd $\mathrm{V}_{2} \mathrm{O}_{5}$. - Nearly neutralize the combined filtrates (B) with $\mathrm{NaOH}$ and pour the solution (not over $100 \mathrm{ml}$ in volume) slowly and with constant stirring into $150 \mathrm{ml}$ of a 10 per cent solution of $\mathrm{NaOH}$ containing $1.0 \mathrm{~g}$ of $\mathrm{Na}_{2} \mathrm{O}_{2}$. Digest on the steam bath for 1 hour to oxidize the chromium to chromate and to decompose the excess of peroxide, cool, and filter through a paper which has been treated with $\mathrm{NaOH}$ of the same strength. This treatment of the paper will prevent the extraction of coloring matter from the paper. Wash the precipitate with hot water and reserve it for the determination of $\mathrm{Fe}_{2} \mathrm{O}_{3}, \mathrm{TiO}_{2}$, and $\mathrm{ZrO}_{2}(\mathrm{C})$. Determine the chromium in the filtrate colorimetrically by comparing the color with that obtained by adding a standard solution of chromate to an alkaline solution of the same strength.

After the color comparison acidify the solution and add a very slight excess of $\mathrm{NH}_{4} \mathrm{OH}$ in order to precipitate the aluminum which will also carry down any phosphorus and vanadium present. Do not use an indicator such as methyl red in this precipitation, as its color may subsequently interfere with the determination of vanadium. Litmus is sufficiently sensitive, as phosphorus and vanadium will not be lost unless a large excess of $\mathrm{NH}_{4} \mathrm{OH}$ is added. The precipitation with $\mathrm{NH}_{4} \mathrm{OH}$ at this point is introduced to get rid of the $\mathrm{Na}_{2} \mathrm{SO}_{4}$ which would otherwise interfere with the precipitation of phosphorus. Incidentally, the most of any chromium and of elements such as platinum and molybdenum are also removed. Filter, dissolve the precipitate in $100 \mathrm{ml}$ of dilute $\mathrm{HNO}_{3}$ (1:9), and add a few drops of $\mathrm{H}_{2} \mathrm{O}_{2}$. If any color develops, compare with a standard solution of vanadium under the same conditions.

After the vanadium has thus been determined colorimetrically, transfer the solution to a $300 \mathrm{ml}$ Erlenmeyer flask and destroy the $\mathrm{H}_{2} \mathrm{O}_{2}$ by boiling vigorously for one or two minutes and then adding a saturated solution of $\mathrm{KMnO}_{4}$ dropwise until a pink color persists. Decolorize by the addition of a few drops of $\mathrm{H}_{2} \mathrm{SO}_{3}$, add $15 \mathrm{ml}$ of $\mathrm{HNO}_{3}$ (sp. gr. 1.42), cool, adjust the volume to about $125 \mathrm{ml}$, and add $40 \mathrm{ml}$ of dilute $\mathrm{NH}_{4} \mathrm{OH}$ (sp. gr. 0.96) and $40 \mathrm{ml}$ of molybdate reagent. ${ }^{7}$ Shake for 10 minutes, allow to stand for one-half hour, filter and wash the flask, paper, and precipitate 10 times with a 1 per cent solution of $\mathrm{KNO}_{3}$. Return the precipitate and paper to the precipitating flask, add an excess of standard $0.1 \mathrm{~N} \mathrm{NaOH}$ and $25 \mathrm{ml}$ of water (both free from $\mathrm{CO}_{2}$ ), and shake until the precipitate is dissolved. Dilute to $100 \mathrm{ml}$, add three drops of a 0.2 per cent

\footnotetext{
7 For the preparation of this reagent mix $100 \mathrm{~g}$ of pure $\mathrm{MoO}_{3}$ or $118 \mathrm{~g}$ of 85 per cent molybdic acid with $400 \mathrm{ml}$ of water and add $80 \mathrm{ml}$ of $\mathrm{NH}_{4} \mathrm{OH}$ (sp. gr. 0.90). When solution is complete, filter and pour the solution slowly and with constant stirring into a mixture of $400 \mathrm{ml}$ of $\mathrm{HNO}_{3}$ (sp. gr. 1.42) and $600 \mathrm{ml}$ of water. Let settle for 24 hours and use the clear supornatant liquid.
} 
solution of phenolphthalein, and discharge the pink color with standard acid. Finish the titration by adding standard alkali until the pink color reappears. The alkali solution is preferably standardized against the Bureau of Standards acid potassium phthalate or benzoic acid, and the ratio of $\mathrm{P}_{2} \mathrm{O}_{5}$ to $\mathrm{NaOH}$ should be considered as $1: 46$ in calculating results.

If it is preferred, the phosphorus may be determined gravimetrically by solution of the phosphomolybdate and double precipitation by magnesia mixture. ${ }^{8}$

As the reagents may contain phosphorus, a careful blank carried through all steps of the determination is essential. It is desirable that a known amount of aluminum corresponding to that in the regular analysis be added to the blank. If aluminum is not added, the most if not all of the phosphorus in the reagents would be lost in the precipitation with $\mathrm{NH}_{4} \mathrm{OH}$, while in the regular determination it would be carried down by the aluminum present in the sample. The results for phosphorus would then be correspondingly high.

(g) Determination of $\mathrm{Fe}_{2} \mathrm{O}_{3}, \mathrm{TiO}_{2}$, and $\mathrm{ZrO}_{2}\left(\mathrm{HfO}_{2}\right)$.-Dissolve the reserved precipitate $(\mathrm{C})$ in $25 \mathrm{ml}$ of hot dilute $\mathrm{HCl}(1: 2)$, add $4 \mathrm{~g}$. of tartaric acid, dilute with water to a volume of $200 \mathrm{ml}$, and neutralize with $\mathrm{NH}_{4} \mathrm{OH}$. Add $2 \mathrm{ml}$ of $\mathrm{HCl}$ per $100 \mathrm{ml}$ of solution, heat to boiling, and saturate with $\mathrm{H}_{2} \mathrm{~S}$. Allow to cool and filter off any platinum sulphide which may have separated and wash with a 1 per cent solution of $\mathrm{H}_{2} \mathrm{SO}_{4}$ saturated with $\mathrm{H}_{2} \mathrm{~S}$. Render the filtrate slightly ammoniacal, pass in a rapid stream of $\mathrm{H}_{2} \mathrm{~S}$ for five minutes, and digest at the side of the steam bath $\left(40^{\circ} \mathrm{C}\right.$.) 15 to 30 minutes. Filter and wash with a dilute solution of $\left(\mathrm{NH}_{4}\right)_{2} \mathrm{~S}(5: 95)$ containing $5 \mathrm{~g}$ of $\mathrm{NH}_{4} \mathrm{Cl}$ per liter. Reserve the filtrate (D).

Dissolve the iron sulphide in hot dilute $\mathrm{HCl}(1: 1)$ to which has been added a little $\mathrm{KClO}_{3}$, evaporate to dryness, take up in $25 \mathrm{ml}$ of dilute $\mathrm{HCl}(5: 95)$, and add $\mathrm{KMnO}_{4}$ until the usual pink color is obtained. Reduce with $\mathrm{SnCl}_{2}$ and titrate slowly with a standard solution of $\mathrm{KMnO}_{4}$, as in the Zimmermann-Reinhardt method.

The filtrate (D) contains the titanium and zirconium. Acidify this solution with $\mathrm{H}_{2} \mathrm{SO}_{4}$, dilute to $200 \mathrm{ml}$, adjust the acidity so that the solution contrains $10 \mathrm{ml}$ of $\mathrm{H}_{2} \mathrm{SO}_{4}$, sp. gr. 1.84 per $100 \mathrm{ml}$, and cool in ice water. It is unnecessary to destroy tartaric acid. Precipitate the titanium and zirconium with an excess of a cold 6 per cent water solution of cupferron. ${ }^{9}$ An excess of the precipitant is indicated by the formation of a fine white precipitate which redissolves, instead of a curdy one which persists. Stir in a little macerated paper, allow to settle for five minutes, filter by suction through

8 G. E. F. Lundell and J. I. Hoffman, Ind. Eng. Chem., 15, pp. 44 and 171; 1923.

9 O. Baudisch, Chem. Ztg., 33, p. 1298; 1909; W. M. Thornton, jr., Am. J. Sci. (4), 37, pp. 173, 407; 1914; W. M. Thornton, jr., and E. M. Hayden, jr., ibid. (4), 38, p. 137; 1914; G. E. F. Lundell and H. B. Knowles, J. Am. Chem. Soc., 42, p. 1439; 1920. 
a paper and cone, and test the filtrate for complete precipitation. Thoroughly wash the precipitate with cold dilute $\mathrm{HCl}(1: 9)$. Transfer to a weighed platinum crucible, carefully dry, then cautiously char and burn the carbon, and finally heat at approximately $1,200^{\circ} \mathrm{C}$. over a blast lamp or its equivalent. Cool in a desiccator, weigh as $\mathrm{ZrO}_{2}+\mathrm{TiO}_{2}$, and repeat the ignition until constant weight is obtained. The correction of the weighed oxides for $\mathrm{SiO}_{2}$ by direct treatment with $\mathrm{H}_{2} \mathrm{SO}_{4}$ and $\mathrm{HF}$ is a difficult procedure and is wellnigh impossible if the residue is large. The amount of $\mathrm{SiO}_{2}$ is usually small and can be determined if desired by evaporating the $\mathrm{H}_{2} \mathrm{SO}_{4}$ solution of the pyrosulphate melt obtained in the next step to fumes of $\mathrm{H}_{2} \mathrm{SO}_{4}$, diluting so that the solution contains 10 per cent of the acid by volume, and recovering the $\mathrm{SiO}_{2}$ by filtering and washing.

Fuse the precipitate of $\mathrm{TiO}_{2}$ and $\mathrm{ZrO}_{2}$ with a small amount of $\mathrm{K}_{2} \mathrm{~S}_{2} \mathrm{O}_{7}$, dissolve the melt in $50 \mathrm{ml}$ of dilute $\mathrm{H}_{2} \mathrm{SO}_{4}$ (1:9), add sufficient $\mathrm{H}_{2} \mathrm{O}_{2}$ to oxidize all of the titanium (an excess does no harm), add $0.5 \mathrm{~g}$ of $\left(\mathrm{NH}_{4}\right)_{2} \mathrm{HPO}_{4}$, allow to stand at the side of the steam bath $\left(40^{\circ}\right.$ C. $)$ overnight, filter, wash with a 5 per cent solution of $\mathrm{NH}_{4} \mathrm{NO}_{3}$, ignite and weigh as $\mathrm{ZrP}_{2} \mathrm{O}_{7}$. Calculate to $\mathrm{ZrO}_{2}$ and subtract from the total weight of $\mathrm{TiO}_{2}+\mathrm{ZrO}_{2}$. As a check, titanium can be determined colorimetrically, before the precipitation of zirconium. In very accurate analyses the $\mathrm{ZrP}_{2} \mathrm{O}_{7}$ should be fused with a little $\mathrm{K}_{2} \mathrm{~S}_{2} \mathrm{O}_{7}$, the melt dissolved in 10 per cent $\mathrm{H}_{2} \mathrm{SO}_{4}$ as before, and the precipitation repeated. More phosphate must be added in the second precipitation, and an excess of $\mathrm{H}_{2} \mathrm{O}_{2}$ should be present at all times.

(h) Determination of Lime and Magnesia.-For the determinations of $\mathrm{CaO}$ and $\mathrm{MgO}$ a new and larger sample (1-5 g according to the quantity of $\mathrm{CaO}$ and $\mathrm{MgO}$ expected) should be used. Put the sample into solution by fusing with $\mathrm{Na}_{2} \mathrm{CO}_{3}$ or treating with $\mathrm{HF}$, $\mathrm{HNO}_{3}$, and $\mathrm{H}_{2} \mathrm{SO}_{4}$, as directed under "Solution of the sample." If the solution of the sample is accomplished by fusion with $\mathrm{Na}_{2} \mathrm{CO}_{3}$, $\mathrm{SiO}_{2}$ must be eliminated. Nearly neutralize the $\mathrm{SiO}_{2}$-free solution with $\mathrm{NaOH}$, dilute to $100 \mathrm{ml}$, and pour slowly and with constant stirring into $150 \mathrm{ml}$ of a 10 per cent solution of $\mathrm{NaOH}$ containing $1.0 \mathrm{~g}$ of $\mathrm{Na}_{2} \mathrm{CO}_{3}$. If the sample does not contain iron, it is advisable to make sure of complete precipitation of titanium and to aid the agglomeration of calcium and magnesium by adding about $0.01 \mathrm{~g}$ of iron as $\mathrm{FeCl}_{3}$ to the solution of the sample before pouring it into the $\mathrm{NaOH}-\mathrm{Na}_{2} \mathrm{CO}_{3}$ solution. Digest on the steam bath for onehalf hour, allow to cool, filter, and wash a few times with a 1 per cent solution of $\mathrm{Na}_{2} \mathrm{CO}_{3}$.

Dissolve the precipitate in $25 \mathrm{ml}$ of hot dilute $\mathrm{HCl}(1: 2)$, and in this solution precipitate the iron, titanium, etc., by addition of a slight excess of $\mathrm{NH}_{4} \mathrm{OH}$, using methyl red as indicator. Filter, 
dissolve the precipitate, and repeat the precipitation with $\mathrm{NH}_{4} \mathrm{OH}$. If it seems desirable to determine iron (provided no iron was added) titanium, and zirconium on a large sample, the precipitate obtained here may be dissolved in $\mathrm{HCl}$ and the iron, titanium, and zirconium determined as previously described. In the combined filtrates precipitate the calcium as oxalate in slightly ammoniacal solution, filter, and wash with a cold 1 per cent solution of $\left(\mathrm{NH}_{4}\right)_{2} \mathrm{C}_{2} \mathrm{O}_{4}$.

Dissolve the precipitate in a small amount of hot dilute $\mathrm{HCl}$ and repeat the precipitation of calcium in a volume of $50 \mathrm{ml}$. Filter, wash as before, ignite, and weigh as $\mathrm{CaO}$.

Combine the filtrates from the calcium determination, acidify with $\mathrm{HCl}$, and precipitate the magnesium by adding $2 \mathrm{~g}$ of $\left(\mathrm{NH}_{4}\right)_{2} \mathrm{HPO}_{4}$ to the cold acid solution, then $\mathrm{NH}_{4} \mathrm{OH}$ slowly and with stirring until the solution is just alkaline and finally $10 \mathrm{ml}$ in excess. Allow the solution to stand for at least 12 hours, filter, dissolve the precipitate in dilute $\mathrm{HCl}$, and repeat the precipitation in a volume of $50 \mathrm{ml}$. A few crystals of $\left(\mathrm{NH}_{4}\right)_{2} \mathrm{HPO}_{4}$ should be added to the acid solution before the second precipitation. Dry the paper and precipitate in a weighed crucible, char without inflaming, burn the carbon at a temperature below $700^{\circ} \mathrm{C}$, and finally heat at $1,000^{\circ}$ to $1,100^{\circ} \mathrm{C}$. Cool in a desiccator and weigh as $\mathrm{Mg}_{2} \mathrm{P}_{2} \mathrm{O}_{7}$.

(i) Determination of the Alkalies.-Alkalies can be satisfactorily determined by the J. Lawrence Smith method.

\section{ROUTINE METHOD FOR THE DETERMINATION OF ALUMINA IN BAUXITE OR REFRACTORIES OF HIGH ALUMINA CONTENT}

Transfer $2.000 \mathrm{~g}$ of the dried sample to a platinum dish and add $25 \mathrm{ml}$ of water, $15 \mathrm{ml}$ of concentrated $\mathrm{H}_{2} \mathrm{SO}_{4}, 25 \mathrm{ml}$ of concentrated $\mathrm{HNO}_{3}$, and about $20 \mathrm{ml}$ of HF. Cover the dish with a platinum cover and digest on the steam bath for 15 to 30 minutes with occasional stirring. Remove the cover, place the dish over a low flame, and evaporate to copious fumes of $\mathrm{H}_{2} \mathrm{SO}_{4}$. Cool, thoroughly wash the inside surface of the dish with a jet of water, mix the contents of the dish thoroughly, and again place over the flame. Heat to incipient fumes of $\mathrm{H}_{2} \mathrm{SO}_{4}$, cool, add $50 \mathrm{ml}$ of warm water, and heat until the salts are in solution. If the solution is not entirely clear, add a little macerated paper, filter, wash with hot water, and reserve the filtrate (A). Ignite the paper and residue in a platinum crucible and fuse with the minimum quantity of $\mathrm{Na}_{2} \mathrm{CO}_{3}$. Cool the melt and dissolve it in an excess of dilute $\mathrm{H}_{2} \mathrm{SO}_{4}$.

If the ignited insoluble residue was small (less than 1 to $2 \mathrm{mg}$ ), add the solution of the melt directly to the reserved filtrate (A). If the ignited insoluble residue was large, as is usually the case with high

1 (For example, approximately 15 per cent of the sample was undissolved in tests of a refractory containing 32.38 per cent of $\mathrm{SiO}_{2}$ and 59.39 per cent of $\mathrm{Al}_{2} \mathrm{O}_{3}$. 
alumina refractories ${ }^{10}$ it may contain some $\mathrm{SiO}_{2}$. In this case add $\mathrm{HF}$ and evaporate the solution to incipient fumes of $\mathrm{H}_{2} \mathrm{SO}_{4}$. Cool, wash down the sides of the dish, and evaporate as before. Cool, add $50 \mathrm{ml}$ of warm water, and add the solution to the reserved filtrate (A).

When the sample is completely dissolved, cool, transfer it to a $500 \mathrm{ml}$ graduated flask, dilute to the mark, mix, and remove with a pipette (1) a $100 \mathrm{ml}$ portion for precipitation by $\mathrm{NH}_{4} \mathrm{OH}$, (2) a $100 \mathrm{ml}$ portion for precipitation by cupferron, and (3) a 200 or $250 \mathrm{ml}$ portion for the determination of $\mathrm{P}_{2} \mathrm{O}_{5}$. (If the percentage of $\mathrm{P}_{2} \mathrm{O}_{5}$ is low, it is advisable to take as large an aliquot as possible.)

(a) Precipitation by Ammonium Hydroxide.-Dilute the first aliquot to $350 \mathrm{ml}$, add a few drops of methyl red indicator, and proceed as in the umpire method, but make only one precipitation by $\mathrm{NH}_{4} \mathrm{OH}$. The weighed precipitate will contain the $\mathrm{Al}_{2} \mathrm{O}_{3}, \mathrm{Fe}_{2} \mathrm{O}_{3}$, $\mathrm{TiO}_{2}, \mathrm{ZrO}_{2}, \mathrm{P}_{2} \mathrm{O}_{5}, \mathrm{~V}_{2} \mathrm{O}_{5}$, and more or less of the $\mathrm{Cr}_{2} \mathrm{O}_{3}{ }^{11}$ which were present in the sample.

(b) Precipitation of $\mathrm{Fe}_{2} \mathrm{O}_{3}$, $\mathrm{TiO}_{2}$, etc., by Cupferron.-Neutralize the second aliquot with $\mathrm{NH}_{4} \mathrm{OH}$, add $40 \mathrm{ml}$ of dilute, $\mathrm{H}_{2} \mathrm{SO}_{4}$ $(1: 1)$, dilute to $200 \mathrm{ml}$, and cool in ice water. Precipitate with an excess of a cold 6 per cent water solution of cupferron, filter, wash, ignite, and weigh as in the umpire method for $\mathrm{TiO}_{2}$ and $\mathrm{ZrO}_{2}$. . The weighed residue contains the $\mathrm{Fe}_{2} \mathrm{O}_{3}, \mathrm{TiO}_{2}, \mathrm{ZrO}_{2}$, and $\mathrm{V}_{2} \mathrm{O}_{5}$ which were present in the sample. Subtract this weight from that of the $\mathrm{NH}_{4} \mathrm{OH}$ precipitate to obtain the weight of the $\mathrm{Al}_{2} \mathrm{O}_{3}+\mathrm{P}_{2} \mathrm{O}_{5}+\mathrm{Cr}_{2} \mathrm{O}_{3}$ in a $0.4000 \mathrm{~g}$ sample.

(c) Determination of $\mathrm{P}_{2} \mathrm{O}_{5}$. - Nearly neutralize the third aliquot with $\mathrm{NaOH}$ and pour it slowly and with constant stirring into $100 \mathrm{ml}$ of a 10 per cent solution of $\mathrm{NaOH}$. Allow the precipitate to settle, filter, and wash a few times with a 1 per cent solution of $\mathrm{NaOH}$. Acidify the filtrate with $\mathrm{HNO}_{3}$, and precipitate the aluminum and phosphorous by the addition of a slight excess of $\mathrm{NH}_{4} \mathrm{OH}{ }^{12}$ Filter wash the precipitate a few times with a 2 per cent solution of $\mathrm{NH}_{4} \mathrm{NO}_{3}$. By the use of a spatula transfer the bulk of the precipitate from the paper to the beaker in which the precipitation was made, add $100 \mathrm{ml}$ of dilute $\mathrm{HNO}_{3}$ (sp. gr. 1.135), heat and digest until the precipitate is dissolved. Pour this solution through the paper to remove any remaining precipitate and catch the clear solution in a $300 \mathrm{ml}$ Erlenmeyer flask. Cool the solution to room temperature, add $40 \mathrm{ml}$ of dilute $\mathrm{NH}_{4} \mathrm{OH}$ (sp. gr. 0.96) and $40 \mathrm{ml}$ of molybdate reagent, shake

11 The proportion of the original chromium that is caught in the $\mathrm{NH}_{4} \mathrm{OH}$ precipitate is a matter of doubt because of possible oxidation during solution of the sample. Moreover, partial oxidation of the oxide $\mathrm{Cr}_{2} \mathrm{O}_{3}$ may occur during ignition. Fortunately, so little chromium is usually present in the original material that it can be ignored. In the exceptional case it is best to make sure of its complete oxidation to the sexivalent state during solution of the sample.

12 The precipitation of phosphorus as ammonium phosphomolybdate is slow or incomplete in the presence of titanium or of large quantities of $\mathrm{Na}_{2} \mathrm{SO}_{4}$. Titanium is removed by the first and sodium salts by the second treatment. 
for 10 minutes, allow to stand for one-half hour, and proceed as described in the umpire method. Calculate the percentage of $\mathrm{P}_{2} \mathrm{O}_{5}$ in the sample and subtract from the percentage of $\mathrm{Al}_{2} \mathrm{O}_{3}+$ $\mathrm{P}_{2} \mathrm{O}_{5}+\mathrm{Cr}_{2} \mathrm{O}_{3}$, found above.

The routine method can be used as an umpire method if the following refinements are added: (1) Repeat the precipitation with $\mathrm{NH}_{4} \mathrm{OH}$ and correct the ignited and weighed precipitate for $\mathrm{SiO}_{2}$; (2) carefully ignite the cupferron precipitate at a low temperature, fuse it with $\mathrm{K}_{2} \mathrm{~S}_{2} \mathrm{O}_{7}$, and repeat the precipitation with cupferron.

If a more complete analysis is desired, the precipitate obtained by $\mathrm{NaOH}$ preliminary to the determination of phosphorous can be analyzed for $\mathrm{Fe}_{2} \mathrm{O}_{3}, \mathrm{TiO}_{2}, \mathrm{ZrO}_{2}$, etc.

Three analyses of the Bureau of Standards standard sample of bauxite No. 69 by the routine method gave $55.02,55.22$, and 54.76 per cent of $\mathrm{Al}_{2} \mathrm{O}_{3}$ as against the certificate value of 55.06. ${ }^{13} \quad \mathrm{~A}$ single run in which the $\mathrm{NH}_{4} \mathrm{OH}$ and cupferron precipitations were repeated gave 54.92. Two analyses of the bureau's burnt refractory No. 77 gave 59.40 and 59.60 per cent of $\mathrm{Al}_{2} \mathrm{O}_{3}$ by the routine method as against the certificate value of 59.39 per cent. ${ }^{14}$ Double precipitations by $\mathrm{NH}_{4} \mathrm{OH}$ and cupferron gave 59.18 and 59.38 per cent.

\footnotetext{
13 This sample also contains 5.66 per cent of $\mathrm{Fe}_{2} \mathrm{O}_{3}, 3.07$ per cent of $\mathrm{TiO}_{2}, 0.08$ per cent of $\mathrm{ZrO}_{2}, 0.11$ per cent of $\mathrm{P}_{2} \mathrm{O}_{5}, 0.03$ per cent of $\mathrm{V}_{2} \mathrm{O}_{3}$, and 0.04 per cent of $\mathrm{Cr}_{2} \mathrm{O}_{3}$.

14 This sample also contains 0.90 per cent of $\mathrm{Fe}_{2} \mathrm{O}_{3}, 2.93$ per cent of $\mathrm{TiO}_{2}, 0.09$ per cent of $\mathrm{ZrO}_{2}, 0.45$ per cent of $\mathrm{P}_{2} \mathrm{O}_{5}$, and 0.032 per cent of $\mathrm{V}_{2} \mathrm{O}_{5}$.
}

Washington, October 31, 1927. 


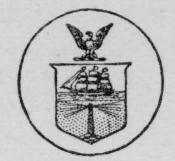

\section{Bureau of Standards JOURNAL OF RESEARCH}

Beginning July, 1928, a new periodical to be known as the

"Bureau of Standards Journal of Research" supersedes and continues the two series of research publications heretofore issued under the designations "Scientific Papers of the Bureau of Standards," and "Technologic Papers of the Bureau of Standards."

Forty-four volumes of the two superseded series have been published. The 22 volumes of scientific papers issued by the bureau (since 1904) contain some 572 research papers on fundamental science, and the 22 volumes of technologic papers (issued since 1910) contain some 370 research papers on applied science.

The new Bureau of Standards Journal of Research will publish the results of the bureau's researches (both theoretical and experimental). It is expected the monthly issues will range from 100 to 300 pages, an average issue containing about 200 pages. Subscriptions $(\$ 2.75$ per year, United States, Canada, and Mexico) should be placed direct with the "Superintendent of Documents, Government Printing Office, Washington, D. C." ( $\$ 3.50$ for foreign subscriptions.)

Shortly after each month's Journal is nublished, reprints of the separate articles contained may be purchased from the Superintendent of Documents. 